\title{
$3-2-48$ ミリビデオ
}

正会員 弓 手康 史 $^{\dagger}$

\section{1. 総一規格の成立}

Timeplex 技術を中心とするビデオ信号のベースバ ンド記録方式の規格化をめぐって，1年間期間を延長 して審議したが，コストパフォーマンス上， $\mathrm{A}$ 規格 としてすでに固まっていた低域変換色度記録方式に勝 る実現技術が見つからなかったため，8ミリビデオ廫 談会は，1984 年 4 月，この $\mathrm{A}$ 規格を統一規格とする ことに合意した。さらに，これを国際標準規格とする ために，IEC 記録技術委員会に付託した。また，シン ボルマークも同懇談会で定め, 50 余力国に商標出願 の手続きをすませた。

8 ミリビデオは, VTRでは初めて内外の業界各社 の合議で規格化され, かつ種々の特徵を有するため, 今後ビデオの応用範囲をますます拡げるシステムとし て大きな期待をもって迎えられている。ささらに625/ 50 システムでは, ビデオディスクと同じく, PALSECAM トランスコーダによりパッケージの交流を 図ったことも高く評価されている。規格の詳細と規格

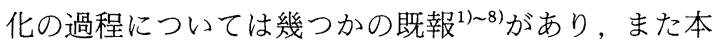
誌 5 章にも主要パラメータが紹介されているので，そ れらを参照いただきながら，ここでは徒来システムに はない特徴的アイテムについて紹介することとした い. 規格化過程で審議されたユニークな対案につい て，ここでも紙面の制約で詳述できないことを残念に 思う。

\section{2. 規格の特 徵}

8 ミリビデオは，ホームムービーへの小型化の憧れ から出発した．テープヘッドを中心とする磁気記録技 術の進歩発展は, 回路の高度集積化や撮像の固体化と

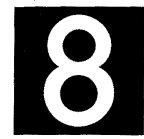

図 1 システムマーク

$\dagger$ 株式会社日立製作所 家電研究所

"3-2-4 8 mm Video System, Peculiarities of the Design Standard and its Forward Development" by Yasufumi Yumde (Consumer Products Research Center, Hitachi, Ltd., Yokohama)
相まって，その実現を可能にした。

記録パラメータの変遷 ${ }^{9}$ にみる, テープ系性能が $C / N$ で $9 \mathrm{~dB}$ 向上すれば現行 $1 / 2$ インチ VTR の標準 モードと同等の画質が 8 ミリVTR で得られ，記録面 積は約 $1 / 4$ に減少する。 $C / N$ がさらに向上すれば長 時間録画も可能となる。

最近のメタル粉テープ $(\mathrm{MP})$, 蒸着テープ $(\mathrm{ME}) の$ 性能は図 3 のように画期的であり，その実用化は後述 のようにメタル材磁気へッドの開発と相まって, その

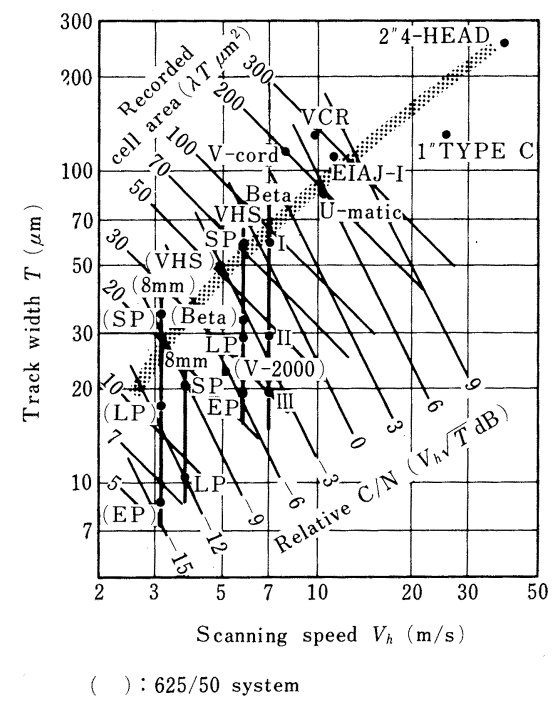

図 2 VTR 記録パラメータの変遷

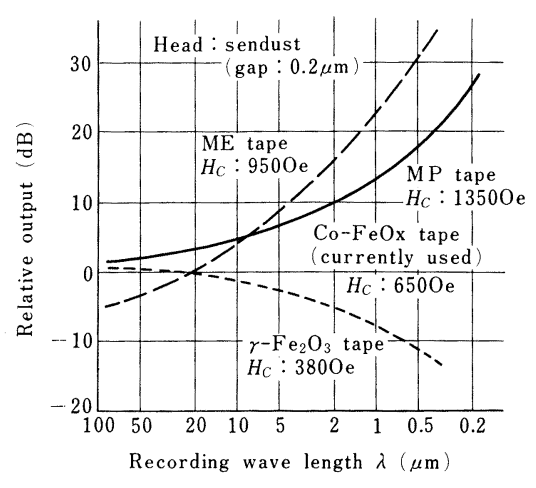

図 3 ビデオテープの相対出力特性例 ${ }^{10)}$ 


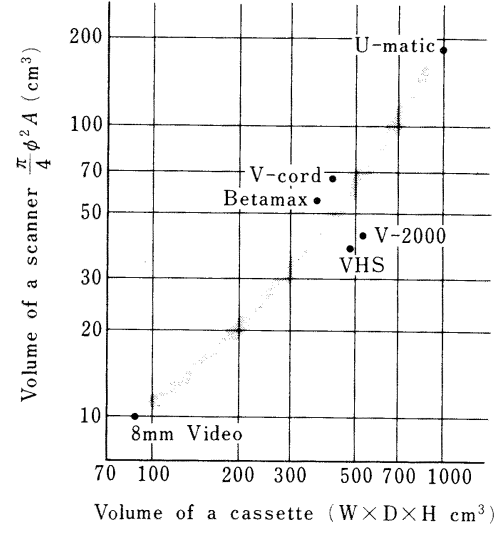

図 4 カセットVTRの機構要素の体積比較

所要 $C / N$ を満足するレベルに達している。この記録 面積の低減は機構要素の体積を飛躍的に減小させ, シ ステムの飛躍的な小型化を約束している。しかも録面 時間は, 標準モード SPで 90 分 $(625 / 50$ で 60 分),

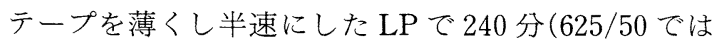
180 分, さらに半速化も記録フォーマット上可能で, その場合 360 分) など, ムービーユースとして，また さらに応用を拡げるに充分な長さを有している.

\section{1 記録フォーマットと信号スペクトラム}

ムービーユースとして編集, アフレコ, ダビング, さらには静止, 分解, 速見などが, 性能劣化少なくで

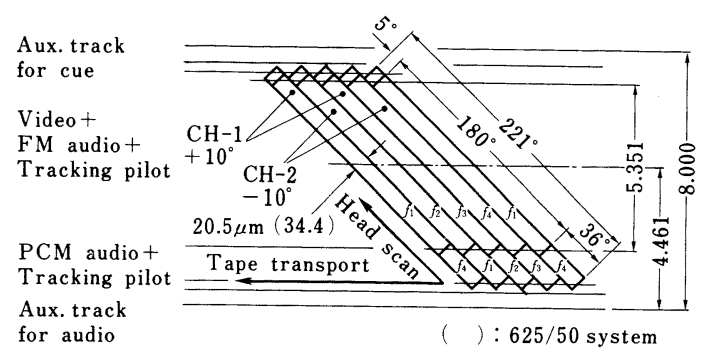

図 5 テープ磁性面上の記録跡パターン

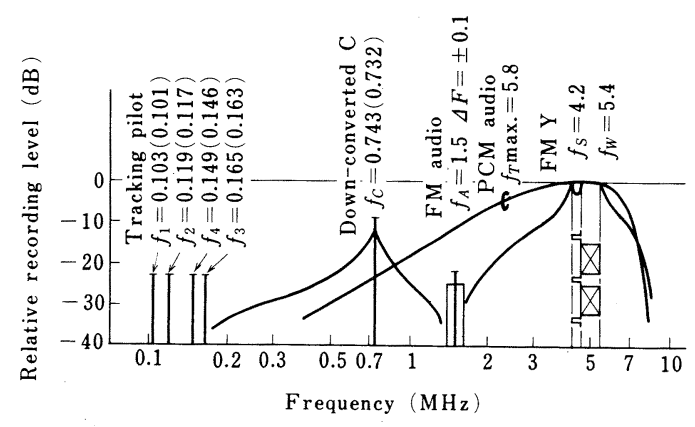

( ) $: 625 / 50$ system

図 6 記録信号の周波数スペクトラム
きなければならない。そのため図 5 ，図6に示すよう に, 回転 2 ヘッド FM 記録を基本方式とし, 特に, ビデオトラックの延長上に PCM オーディオエリアを 設けたこと, トラッキングパイロットや FM オーデ イオをビデオ信号に多重記録したこと, 輝度色度帯域 拡大のためそれらのキャリヤを高めにしたことが特徵 的である.このフォーマットは, すべての信号を回転 ヘッド記録とすることでトランスポートが単純とな り，鏡面仕上げされた薄手テープの走行が容易になる よう考慮されている.

\section{2 テープ，カセット}

テープローディング機構の設計の自由度を高めるた めに, カセットには広い引出しロが設けられている。 それにはテープの保護が必要で, そのため内外二重の 保護蓋と, ローディングをはじめなければ解けないリ ールロック機構が設けられている.さらに, テープ種 類識別ホール, リバーシブル誤消去防止爪, チェンジ ヤグリップなどが用意されている.使用テープは $\mathrm{MP}, \mathrm{ME}$ (等価特性テープを含む)の 2 種, 諸特性は 8 ミリビデオ懇談会が定めたリファレンステープを基 準としている.カセットにはP 6-90，E 5-60などの 形名が付される. $\mathrm{P}, \mathrm{E}$ は $\mathrm{MP}, \mathrm{ME}$ の別, 6, 5 は 525/60，625/50 システムの別，90, 60 はそのシステ ム下での標準録画時間(分)を表している.LP モード での録画実時間は，したがって表示の 2 倍となる.

\section{3 パイロット信号によるトラッキング制御}

パイロット方式には周波数配置と空間配置とがあ り, 規格化途上比較検討されたが, 若干のコスト差で 4 周波方式がとられた. パイロット周波数のトラック への割付は, アジマスロスの利かない長波長領域に， 両隣を見たその差が $f_{H}, 3 f_{H}$ になるように定められ，

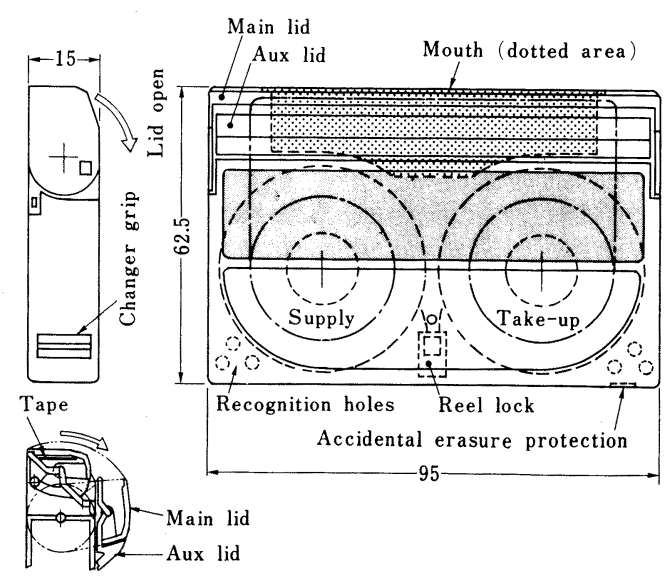

図 7 カセット, 二重蓋構造

テレビジョン学会誌 Vol. 39, No. 4 (1985) 


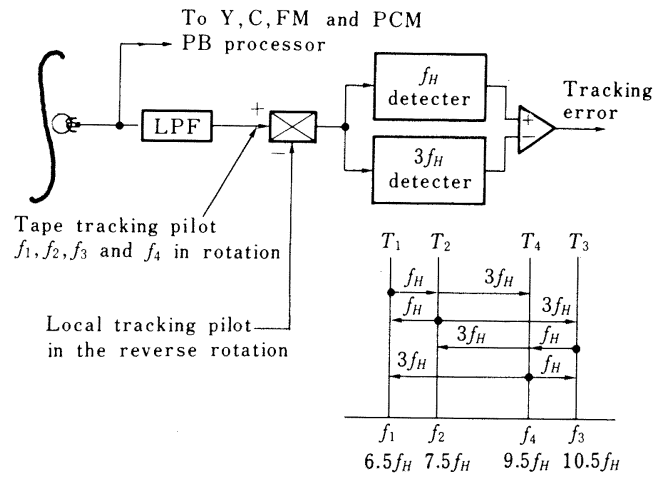

図 8 トラッキングパイロット周波数とエラー検出

フライバックパルス妨害を避けるため $0.5 f_{H}$ のオフセ ットがつけられている. エラーの検出は両隣からのパ イロットの洩れ量の比較でなされる. 図8のように, 再生パイロットの成分をこれとは逆相のローカルパイ ロットで見れば，エラーは常に自トラックから見て走 查が右に寄れば正に，左に寄れば負になる，パイロッ トはPCM エリアにも記録され, その単独再生やビデ オ信号の挿入編集を可能にしている.このパイロット トラッキング方式は, さらに高度の機能が必要になっ たとき, ヘッドの高速位置制御(Dynamic track following) ${ }^{20)}$ を可能にする.

\section{4 色度信号記録}

冒頭述べたように, Timeplex 技術によるベースバ ンド記録方式も検討されたが, 結局低域記録方式で 625/50 システムも一本化された. 基本的には, 輝度 に対する色度の混変調妨害はドットインタレースによ って画面上相殺し，トラック間クロストーク妨害はラ イン相関処理によって減算除去する原理に基づいてい る. 図9に示すように, 両 TVシステムに対するパ イロット発生部を含む回路の共用化と,オフセットキ ヤリヤ発生部の単純化のために, $525 / 60$ では $f_{c}=$

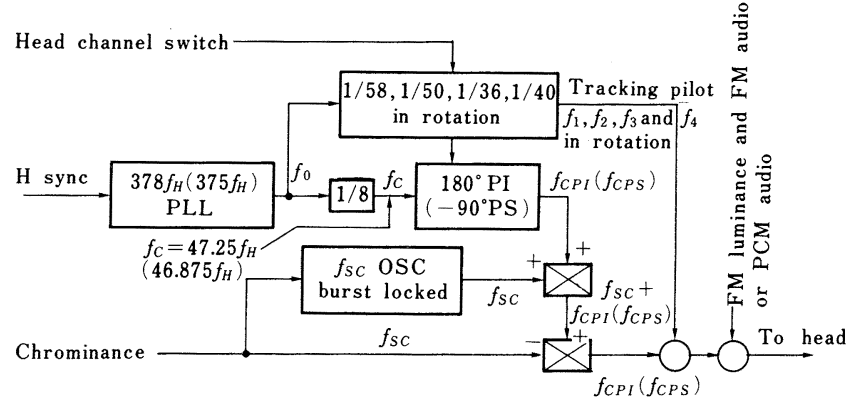

( ) :625/50 system

Down-converted chrominance

図 9 低域変換色度信号, トラッキングパイロット信 号の生成
$47.25 f_{H}, 180^{\circ} \mathrm{PI}, 625 / 50$ では $f_{c}=46.875 f_{H},-90^{\circ}$ PS としたことが特徴的である ${ }^{2229)}$. クロストーク妨 害信号は, $525 / 60$ ではトラック間で $0.5 f_{H}$ インタリ ーブ関係にあるので $1 H$ くし形フィルタで除去でき, $625 / 50$ では $0.25 f_{H}$ の関係なので $2 H$ くし形で除去で きる.スペクトル上隣接するパイロットと FMオー ディオからの妨害を低減するため, $6 \mathrm{~dB}$ のダイナミ ックエンファシスを施し, 帯域いっぱいの伝送を可能 にしている.

\subsection{FM オーディオ記録}

対数レベル圧伸とエンファシスの併用で, テープノ イズ, ヘッド切替ノイズ, 輝度色度妨害, トラック間 クロストーク妨害などを大幅に低隇し, システムを成 立させている。なかでもクロストーク妨害は SPで最 悪 $-17 \mathrm{~dB}, \mathrm{LP}$ ではー $11 \mathrm{~dB}$ にも及ぶが, レベル圧縮 変調による $\mathrm{FM}$ 側帯波の分散効果で $S / N$ が著しく改 善され, SPで約 $80 \mathrm{~dB}, \mathrm{LP}$ でも $70 \mathrm{~dB}$ のダイナミ ックレンジが得られる ${ }^{25) 28)}$. この記録方法は現行 $1 / 2$ インチVTRの音声 HiFi 化にも応用されている.

\subsection{PCM オーディオ記録}

2:1アナログ圧伸と 10-8 ディジタル圧伸の併用 で, テープ上 8 ビット記録が可能となり, 占有エリア

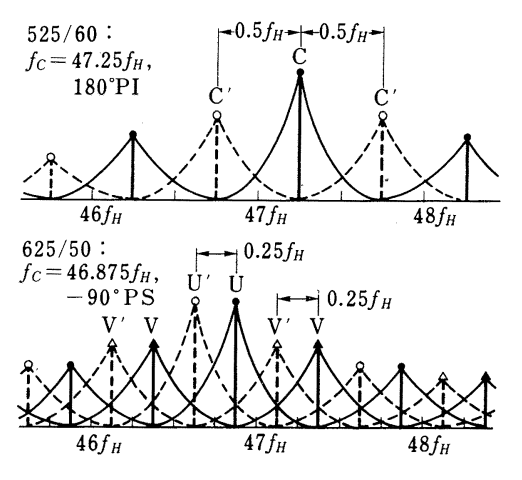

- : Spectra to be recorded by $\mathrm{CH}-1$ head $\circ \Delta$ : The same above by $\mathrm{CH}-2$ head

図 10 低域変換色度信号のスペクトラム

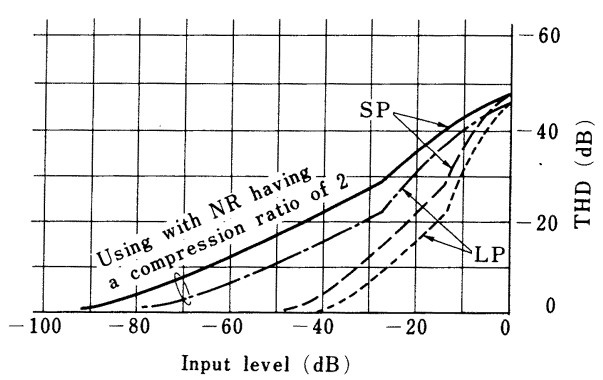

図 11 FM オーディオシステムのダイナミック特性 


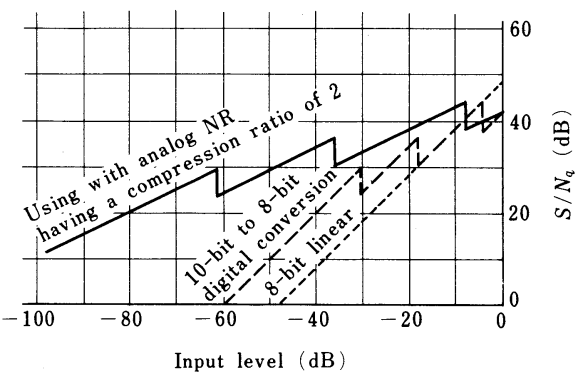

図 12 PCM オーディオシステムのダイナミック特性

表 1 ID ワードの割当

\begin{tabular}{|c|c|c|c|c|c|c|}
\hline & \multicolumn{5}{|c|}{ Utility word (optional) } & \multirow{2}{*}{$\begin{array}{c}\text { Control word } \\
\text { ID } 5\end{array}$} \\
\hline & ID 0 & ID 1 & ID 2 & ID 3 & ID 4 & \\
\hline B7 & \multirow{8}{*}{$\begin{array}{l}\frac{8}{8} \\
8 \\
8 \\
8 \\
z\end{array}$} & \multirow{8}{*}{\multicolumn{4}{|c|}{$\begin{array}{l}\text { Data code } \\
{\left[\begin{array}{l}\text { Program number } \\
\text { Cut number } \\
\text { Year } \\
\text { Month } \\
\text { Day } \\
\text { A day of the week } \\
\text { Hour } \\
\text { Minute } \\
\text { Second } \\
\text { Frame number } \\
\text { etc. }\end{array}\right.}\end{array}$}} & Dubbing protect \\
\hline B6 & & & & & & Start, end and \\
\hline B5 & & & & & & $\mathrm{da}$ \\
\hline B4 & & & & & & $\mathrm{CH} 2$ contents \\
\hline B3 & & & & & & $\mathrm{CH} 1$ contents \\
\hline B2 & & & & & & Mono, stereo or \\
\hline B1 & & & & & & $b_{1}$ \\
\hline B0 & & & & & & Validity of ID 5 \\
\hline
\end{tabular}

は僅か $0.9 \mathrm{~mm}$ (走查角約 $30^{\circ}$ ) となって, $8 \mathrm{~mm}$ のテ ープ幅内にすべてを収容することができた。ダイナミ ックレンジは $90 \mathrm{~dB}$ 以上得られ実用上充分である. VTRにおけるエラー発生パターンを考慮して, 充分 なエラー訂正, 補間性能を得るため, クロスインター リーブコード方式による符号化を行っている．デー夕 構成は， 8 ワード 2 パリティーを 1 ブロックとし， 132 ブロック $(625 / 50$ では 157$)$ を 3 ゾーンに分散配列 にして 1 フィールドとしている. エラー検出は CRC コード方式によりブロック単位で行われる。これによ って, ランダムエラーに対しては, テープ系で普通に 起きるプロックエラーが SP で $10^{-4}, \mathrm{LP} て ゙ 10^{-3.7}$ 程 度，互換で 1 桁近く悪化して $10^{-3}$ 程度となるが，そ こでの訂正不能確率は 1 ワード $/ 2$ 日である.

連続エラーに対しては, エラー長が 24 ブロック $(440 \mu \mathrm{s})$ まで訂正可能で, 以下 44 ブロックまでは 1 ワード補間, 88 ブロックまでは 2 ワード補間となる. $625 / 50$ システムでは同じく, 28 ブロック $(520 \mu \mathrm{s})$, 52 ブロック，104 ブロックであり，共に実用上充分な
余裕を有している ${ }^{4) 5)}$.データワード中には 6 個の ID ワードが用意され，その割当ルールと数種の割当が定 められている。

規格化過程において，世界的に実施されている 32 $\mathrm{kHz}$ サンプリングシステムとのディジタル結合を重 視する提案があったが, 検討の結果, それも重要だが 525/60でのリープフィールド処理やアナログ圧伸の ディジタル化などを考えると，その意味が薄れるた め, むしろテレビシステムと関連をもたせた $2 f_{H}$ サ ンプリング方式が採られた。デジタルコーディング技 術では, 上記のほかにADPCM (Adaptive differential PCM) と ADM (Adaptive delta modulation)が，エラー訂正技術では RSC （Reed-Solomon codes)が提案され，ともに試聴実験を含む比較検討 がなされた。

\section{3. 実現と応用}

まず，MP，MEテープの性能を実用的に引出すこ とが最重要課題となる。 そのため, 八イ $\mu$, 八イ $\mathrm{Bs}$, 対摩耗性を追究した合金ヘッドの開発が, センダスト 薄膜多層, アモルファス薄膜多層の 2 系列で進めら れ, 従来性能比で,メタル材としたことによるしゅう 動ノイズ改善効果を含めて, MPで $10 \mathrm{~dB}$ 以上の $\mathrm{Cl}$ $N$ 向上, $\mathrm{ME}$ では $15 \mathrm{~dB}$ 以上など, $\mathrm{LP} も$ 可能と思わ れる成果が報告されている ${ }^{11) ~ 18)}$ 。また, 薄手テープ の走行負荷を軽減し機構をコンパクトにするため, 完 全固定ヘッドレスを可能にするフライングイレーズヘ ッドの開発も報告された ${ }^{19)}$.

専用LSIの開発も, PCM回路を含めて完了

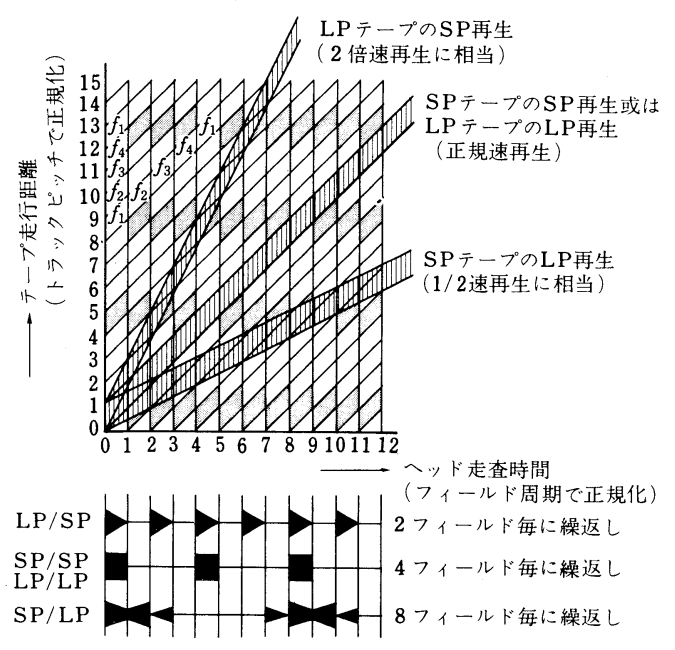

図 13 パイロット再生軌跡と再生エンベロープ $\left(f_{1}\right.$ に着目) (VTRトラックパターン座標法 ${ }^{311} に$ よる) 


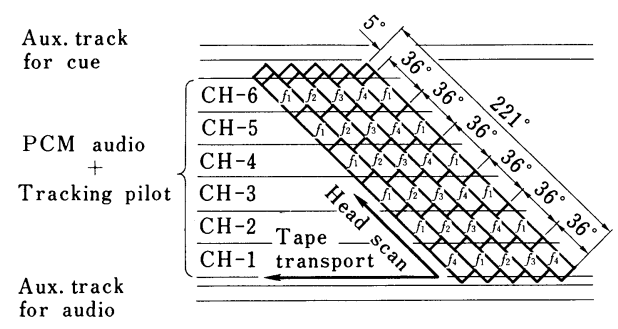

図 14 マルチチャンネル PCM の記録フォーマット例

し2123224), PAL-SECAM トランスコーダの 1 チップ LSI も完成している模様である ${ }^{27)}$.

機能拡張に関しては, LP 化を可能にするモード判 別法が報告されている ${ }^{26)}$.この方法は図示のように， パイロット再生バーストの周期がモードによって異な ることを，その原理としている，PCMオーディオの 多様化のため，6 チャンネル化のフォーマットが提案 され ${ }^{30)}, 1984$ 年の全日本オーディオフェアにおいて も試作機が提示された。 この方法によるマルチ化, 長 時間化の記録，再生は，エリアの単なる選択によって なされるため，ほとんどコストアップなしで実現でき る。

以上, 規格の特徴および実現と応用の一端を紹介し たが，前述のように，かつてない規模での国際的活動 によって規格化されたこのコンパクトなカセットとス キャナと, PCMエリアをもつニューフォーマット は, 今後のビデオの, あるいは $\mathrm{AV}$ システムの新た な分野を拓くものと期待される. (昭和 59 年 12 月 4 日受付)

\section{〔参 考 文 献〕}

1) "Reports on Coordination Committee and Working Groups", the Documents Submitted at the 1st to 6th General Meeting of the $8 \mathrm{~mm}$ Video Conference (Mar. 1982 Apr., 1984)

2) "Recommended design standard on $8 \mathrm{~mm}$ video", published from the $8 \mathrm{~mm}$ Video Conference (Apr., 1984)

3）広全康：“8 ミリビデオ規格統一について”, 電子, 23,5 (1983)

4）広全康：“8 ミリビデオにおける PCM オーディオ”, 1983 電子工業技術大会資料集，2B-3（1983）

5）水島昌洋：“ 8 ミリビデオと音声チャンネル”, JAS Journal, 24, 2 (1984)
6）広田昭：“8 ミリビデオについて (1)”, テレビ学技報, VR 61-1 (Feb., 1984)

7）弓手康史：“8ミリビデオについて $(2) ”$, テレビ学技報, VR 61-2 (Feb., 1984)

8）弓手康史：“ 8 ミリビデオの標準化規格案について”，テレ ビ誌, 38, 3, (Mar., 1984)

9）菅谷汎：“ビデオテープレコーダとその展望”, 日本応用磁 気学会誌, 8,4 (1984)

10）明石五郎：“磁気テープの進歩”, 日本応用磁気学会誌, 7,3 (1983)

11）篠原紘一ほか：“蒸着テープ”, 日本応用磁気学会誌，7，3 (1983)

12）玉川惟正ほか：“メタルテープ”, 日本応用磁気学会誌, 7,3 (1983)

13）柴谷弘道：“薄膜製作技術を用いた磁気記録へッド”，NHK 月報, 20, $10(1977)$

14）猪俣浩一郎ほか：“磁気へッド用アモルファス合金”, 信学 技報, MR 79-14 (Aug., 1979)

15）大浦秀男ほか：“超急冷アモルファス合金による狭トラック ヘッド”；信学技報, MR 83-26（Nov., 1983）

16) K. Matsuura, et al: "Amorphous Video Head for High Coercive Tape”, IEEE Trans., MAG-19, 5 (1983)

17）黑江章郎ほか：“スパッタアモルファスビデオヘッド”, 信 学技報, MR 84-32 (Oct., 1984)

18）安田伊佐雄：“ビデオヘッドの動向”, 日本応用磁気学会誌, 8, 4 (1984)

19) K. Yamashita, et al: "Sendust Sputtered Ferrite Flying Erase Head", IEEE Trans., MAG-20, 5 (1984)

20) “A Description for the Video 2000 System", Issued by Philips (1979)

21) Y. Tanii, et al: "LSI System for $8 \mathrm{~mm}$ Video", IEEE Trans., CE-30, 4 (1984)

22) A. Shibata, et al: "The New Chroma Signal Recording System for $8 \mathrm{~mm}$ Video", IEEE Trans., CE-30, 4 (1984)

23) Th. G. J. A. Martens, et al: "A Versatile PCM IC SET for $8 \mathrm{~mm}$ Video”, IEEE Trans., CE-30, 4 (1984)

24) H. Miyaguchi, et al: "PCM Audio IC's for $8 \mathrm{~mm}$ Video", IEEE Trans., CE-30, 4 (1984)

25) Y. Watatani, et al: "The FM Audio Signal Recording System for $8 \mathrm{~mm}$ video", IEEE Trans., CE-30, 4 (1984)

26）東信雄ほか：“ 8 ミリビデオの録音テープの速度判別の一方 式”,テレビ全大，7-21（1984）

27）秋武勇夫ほか：“1 チップ PAL-SECAM トランスコーダ”, テレビ全大, 7-21 (1984)

28）伊藤滋行ほか：“8 ミリビデオ用 FM オーディオシステム”, テレビ学技報, VR 64-3 (Aug., 1984)

29）畔柳朝光ほか：“8ミリビデオの色信号処理回路”, テレビ 学技報, MR 84-34 (Oct., 1984)

30）“PCM マルチトラックレコーディング暫定仕様”，第 1 回 8 ミリビデオ PCM マルチトラックフォーマット研究会資料 (Dec., 1984)

31) N. Yokobori, et al: "VTR Track-pattern Coordinate Method", National Tech. Rep., 23, 3 (1982) 